\title{
An Analysis of the Need of Teaching Materials Development for Financial Accounting on Character- based Conservation
}

\author{
Kusmuriyanto $^{1}$, Kardiyem ${ }^{2}$, Dwi Puji Astuti ${ }^{3}$, Ridah Yulianti ${ }^{4}$ \\ \{kusmuriyanto@mail.unnes.ac.id $\left.{ }^{1}\right\}$ \\ Universitas Negeri Semarang, Indonesia ${ }^{1,2,3,4}$
}

\begin{abstract}
The study's objective is to analyze the students' needs for teaching materials needed in financial accounting courses. Teaching material is one of the important components required in the learning process. The appropriate teaching materials are expected to support learning activities. The Financial Accounting Course is a compulsory course for accounting education students at Universitas Negeri Semarang. This course consists of the concepts and principles of a business's financial statements and its accounting treatment. It a descriptive exploratory study taking the accounting education students at Universitas Negeri Semarang as the study's subject. The sample used for this study take randomly for 20 students as the samples. The research data obtained from the initial observation and questionnaire results for the desired teaching material. The observations showed that financial accounting teaching materials are still unable to explain the learning content in detail, both in terms of material and visualization. The needs analysis for developing the teaching materials showed that students need teaching materials explaining contextually to be implemented in the real world.
\end{abstract}

Keywords: Teaching Materials, Financial Accounting, Needs Analysis.

\section{Introduction}

Education is one of the important aspects of human life. As time goes by, it improves the quality of education to produce qualified human resources. A certain thing to be improved for the better quality of education is improving teaching effectiveness and efficiency. Education has quite complex activities, covering various components related to each other. If education is done regularly, various elements (components) must be involved in educational activities that need to be recognized. Education can be seen by students, educators, and their other interactions in the education business. The relationship between student elements and educators should not only be one-way in the form of delivering information from teachers to learners. The process of teaching-learning is better if done actively by both parties, namely teachers and students, for a balanced interaction between the two.

The lecturing process is closely related to learning media. One of the most familiar and useful learning media to use is teaching materials. The use of teaching materials of Berkuquality can help teachers to deliver learning materials to the fullest. Teaching materials should be arranged by following a specific rule that Stamatis means that the right teaching materials 
should formulate preparation tailored to establishing the teaching materials. Well-designed and structured teaching materials can affect the level of learning quality.

Stephens [1] explained that the learning quality is strongly influenced by inputs, i.e., human resources and supporting resources. The higher the input readiness, the higher the input [2]. Besides human resources, there are other supporting resources, including facilities and infrastructure, and teaching material. Teaching material is one component needed in the learning process to support the learning process.

Mudlofar [3] stated that teaching materials are all forms of materials used to help students achieve the expected competence. The design of systematic teaching materials greatly influences individual human resources and facilitates teaching and learning processes [4]. Types of teaching materials such as printed materials include books and modules, audio teaching materials, audiovisual teaching materials, and interactive multimedia teaching materials [5]. According to Kristanto [6], Teaching materials or instructional materials outline knowledge of skills and attitudes that students must learn to achieve a predefined competency standard. Some teaching materials include printing materials, such as books, print modules, student worksheets, brochures, leaflets, and wallcharts. Audio, such as video movies and VCD. Multimedia, such as Interactive CD and the Internet.

Impressive teaching materials are needed in the learning process because they can increase students' motivation and interest. Teaching materials are used by educators to teach in various science fields, one of which is financial accounting. Financial accounting is a science that discusses financial records related to transaction logging issues transaction for a company or organization and the preparation of various periodical reports from the recording results. For the science of physics to be delivered well to students, educators need useful teaching materials. Quality teaching materials are one example of useful teaching materials to use.

Then, the classroom's learning process problems are from the teacher-centered learning and ineffective implementation of learning models [7]. Teacher-centered learning makes students passive and bored. On the other hand, Che Ghani et al. [8] explained that graduates should not only understand the concepts, however, but also to practice and to solve problems in the real world.

The study program of Economics Education at the Faculty of Economics, Universitas Negeri Semarang, already applied the 2019 curriculum based on competency and conservation. One of the curriculum demands is that students have academic skills in accounting following science and technology developments. One of the subjects taken by students to support the achievement of those competencies is Financial Accounting. The teaching materials used have been compiled by authors from outside Universitas Negeri Semarang (UNNES) or external parties. It does then consider that there a mismatch of teaching materials with user needs.

The limitation of external parties' teaching materials is that not all material is relevant to the Study Program's required curriculum. It makes students purchase other reference books; it is not a single unit because they are separated from several book references. As prospective teachers, they are required to master the scientific substance related to the field of study. Moreover, they should master personal abilities reflecting the personality [9]. Life values need to be developed into a complementary part of the education curriculum because some students get high grades academically.

Nevertheless, they are failed to treat life well. Hisham [10] stated that effective educators and learning are very important in the learning process. According to Hanifah et al. [11], teachers' quality lies in the competence of teachers and teachers to determine the quality of learning and student achievement. 
The theory developed by Handoyo and Tijan [12] used in the study is regarding the conservation characters, i.e., religious, honest, caring, tolerant, democratic, polite, intelligent, and tough. Religious is an attitude and behavior that reflects submission to God Almighty. Honesty is a union of attitudes, speech, and behavior to be used as a person who can be trusted. Caring is an attitude and behavior like to share, help others, and protect the natural environment. Tolerances are attitudes and actions that can understand and accept other people's opinions. Democratic is an attitude and action which is fundamental to respect for the rights and obligations of others. Polite is an attitude that reflects the refinement of mind and behavior towards others. Intelligence is the ability to know and understand all problems quickly and precisely, and to be able to solve problems wisely. Resilience is the ability to never give up on facing all problems.

Students are problem tackler since they have high confidence, strength, endurance, and enthusiasm. The development of character values carried out by UNNES as a conservation university by inserting those characters in the teaching-learning process.

Based on the Minister of Education and Culture Nadiem Makariem, implementing the 2021 national examination will be abolished. It will be changed to a minimum competency assessment and character survey, consisting of literacy skills, numeracy skills, and strengthening character education (www.cnnindonesia.com). Therefore, there should be efforts to improve the teaching materials internalizing the character conservation values to bridge the need for a conservation-based financial accounting course. It can be done by developing new teaching materials to facilitate students' conceptual reasoning and solve existing problems. It is expected that students can understand the concept of materials learning independently both in theory and practice and understand the conservation values in life. It means that they can support the UNNES programs with a conservation perspective.

They refer to teaching materials of financial accounting based on conservation, where concepts in essential competencies contain life values' characteristics. However, learners not only gain knowledge in theory only, besides the values of life contained. For the study's demands to produce the following expectations, these concepts must be linked to the material. Conservation-based elections will significantly contribute to the lack of students ' knowledge of the environment and their life values. With conservation-based, it will improve students' character, namely indigo-value conservation, and support the program of Universitas Negeri Semarang that is insightful conservation. Therefore, the need for teaching materials that internalize the character's conservation values to bridge the needs.

The study aims to analyze the need for teaching materials in financial accounting at the Department of Economics Education, UNNES. Data are collected by conducting the initial observation and distributing the questionnaire needs sheets. The research results are expected to provide the teaching materials needed and developed to improve students' understanding and interest in learning the financial accounting materials independently and in class.

\section{Research Method}

\subsection{Types of research}

It exploratory, descriptive research. 


\subsection{Time and Place of the Research}

The research conduct in March-April 2020 at the Accounting Education Study Program, Faculty of Economics, Universitas Negeri Semarang (UNNES).

\subsection{The Research Subject}

The subjects of this study are Accounting Education students in the $6^{\text {th }}$ semester at UNNES taking Financial Accounting; they are 93 students. The sample used for this study amount to 20 students taking by simple random sampling.

\subsection{The Research Stages}

The research data obtained from preliminary observations, interviews, and questionnaires. The initial observation is used by researchers to determine the limitations of the teaching materials in the Financial Accounting subject. An interview is an instrument to determine the difficulties and suggestions given by respondents in open questions. A questionnaire is a research instrument to determine the follow-up efforts to address the research subject's problems related to the teaching materials. Then, the researchers can provide appropriate solutions as expected to the research subjects.

The research instruments observation sheets and questionnaires. The data obtained qualitative and quantitative data. The data will be analyzed descriptively using a descriptive percentage system by comparing the number of answers from the research subjects with the highest number of answers with a range of $0-100 \%$ by qualifying the data into existing categories, synthesizing, organizing certain patterns, and making the conclusions.

\section{Result and Discussion}

The research on analyzing student needs for the teaching materials of Financial Accounting. Data conducted using initial observation sheets, research questionnaires, and interview sheets. The instruments distribute to 20 students as the samples of the research. The first instrument is an initial observation to analyze student needs. It follows by filling out questionnaires and interviewing students' needs for teaching materials at the Financial Accounting course.

Researchers' observations during the Financial Accounting showed that most students are difficult to understand the financial accounting courses. Most students showed less enthusiasm for learning due to several factors. Some of the students' obstacles in learning financial accounting are the lack of understanding of the basic knowledge of learning materials, the lack of student participation in class because of a monotonous learning strategy, explaining the material using PowerPoint media, and irrelevant references. The learning strategies would be better if the lecturers encourage students' engagement in the teaching-learning process. The next obstacle is the different learning experiences between senior and junior lecturers. If the learning is only one way, or one direction centering to the lecturers, it made students do not understand the materials, bored. It did not actively participate in the learning process.

The difficulties and obstacles in the teaching-learning process have an impact on students' achievement. To overcome these problems, the lecturers should change the learning method into group presentations and discussions to make students more active and enthusiastic in the learning process. Meanwhile, it can not completely overcome the problems because it only addresses students' activities in the class. The students' understanding is 
completely resolved because the book's language is hard to understand and does not fit the existing curriculum. It also needs more explanation and exercises on questions and answers. The results of research questionnaires can be seen in Table 1.

Table 1. The Questionnaire Results on Students' Needs

\begin{tabular}{|c|c|c|}
\hline No & Item Questions & Percentage of Students Answers \\
\hline 1. & $\begin{array}{l}\text { What learning resources do you use in } \\
\text { financial accounting lectures? }\end{array}$ & $\begin{array}{l}\text { a. Internet: } 30 \% \\
\text { b. Text Book: } 60 \% \\
\text { c. Modules: } 10 \% \\
\text { d. Others: }\end{array}$ \\
\hline 2. & $\begin{array}{l}\text { What type of teaching material do you want } \\
\text { to study in financial accounting? }\end{array}$ & $\begin{array}{ll}\text { a. } & \text { Modules: } 10 \% \\
\text { b. Textbooks: } 50 \% \\
\text { c. Student Worksheet: } 10 \% \\
\text { d. Handout: } 30 \%\end{array}$ \\
\hline 3. & $\begin{array}{l}\text { Did you learn about financial accounting for } \\
\text { teaching materials based on conservation } \\
\text { characters? }\end{array}$ & $\begin{array}{l}\text { a. Yes: } 50 \% \\
\text { b. No: } 50 \%\end{array}$ \\
\hline 4. & $\begin{array}{l}\text { Are financial accounting materials } \\
\text { intangible? }\end{array}$ & $\begin{array}{l}\text { a. Yes: } 65 \% \\
\text { b. No: } 35 \%\end{array}$ \\
\hline 5. & $\begin{array}{l}\text { Do the materials of financial accounting } \\
\text { need to be packaged more contextually? }\end{array}$ & $\begin{array}{l}\text { a. Yes: } 100 \% \\
\text { b. No: } 0 \%\end{array}$ \\
\hline 6. & $\begin{array}{l}\text { Are the financial accounting books/ other } \\
\text { references you use having interesting and } \\
\text { easy to understand pictures? }\end{array}$ & $\begin{array}{l}\text { a. Yes: } 5 \% \\
\text { b. No: } 95 \%\end{array}$ \\
\hline 7. & $\begin{array}{l}\text { Is the language from the financial } \\
\text { accounting book/ other learning sources } \\
\text { today easy to be understood? }\end{array}$ & $\begin{array}{l}\text { a. Yes: } 5 \% \\
\text { b. No: } 95 \%\end{array}$ \\
\hline 8. & $\begin{array}{l}\text { Can you take the character values at the } \\
\text { materials of financial accounting lectures? }\end{array}$ & $\begin{array}{l}\text { a. Yes: } 65 \% \\
\text { b. No: } 35 \%\end{array}$ \\
\hline 9. & $\begin{array}{l}\text { Are the questions in the books of financial } \\
\text { accounting easy to be understood? }\end{array}$ & $\begin{array}{l}\text { a. Yes: } 15 \% \\
\text { b. No: } 85 \%\end{array}$ \\
\hline
\end{tabular}

The analysis results from questionnaires on student needs for developing the teaching materials showed that most students are satisfied with the Financial Accounting; the subject materials are sufficient to meet their needs. $50 \%$ of students chose the supporting facilities used in financial accounting learning in contextually packed teaching materials. Good teaching materials should be self-contained and self-instruction or independent learning. Independent learning can be achieved only if the teaching materials are easy to be understood by students.

Table 1 shows that the financial accounting material's language is still classified as abstract without any direct practices; it made students difficult to understand. There is an incomplete translated book, only a few pictures to improve students' enthusiasm, and the difficult examples of the teaching material problems. The students agreed to develop teaching materials, especially for financial accounting materials, with character conservation. The existence of models, methods, and learning strategies is expected to develop advanced teaching materials.

The analysis results showed that students needed additional teaching materials packaged interestingly to make students understand the course material and learning concepts. It can be 
concluded that researchers are required to provide solutions for solving these problems by developing teaching materials. The development of effective teaching materials could be done by developing textbooks. Textbooks are one type of material used as a guide for students and lecturers in carrying out lecture activities.

The preparation of textbooks is different from reference books in general. It needs to be adjusted to the curriculum at the Study Program personalized to the student's needs, using the communicative language, arranged for the instructional process, and providing the feedback from participants. Nowadays, students only use reference material written from external parties outside Universitas Negeri Semarang. Thus, there are less suitable teaching materials with user needs. Not all material is relevant to the required curriculum in the Study Program. There are many forms of textbooks; one of them is printed textbooks. Printed textbooks are one of the teaching materials that positively impacted students' ability to understand the learning materials. It is in line with the previous study done by Irawati and Saifuddin [13] entitled "The Need Analysis on Developing the Textbook Materials for Biology Prospective Teachers at Biology Education Ahmad Dahlan University, Yogyakarta. The research analysis results showed that students' teaching materials are in textbooks, with teacher history, teacher regulations, teacher competencies, biology teacher competencies, teacher certification, and teacher profiles in other countries.

According to the rules of writing materials issued by the Directorate of Vocational Middle School Directorate General of Primary and Secondary Education Department of National Education year 2003, teaching materials must have several characteristics: selfinstructional, self-contained stand-alone, adaptive, and user-friendly [14]. First, selfinstructional teaching materials can make students able to teach themselves with developed teaching materials. The teaching materials must be formulated objectives to fulfill the selfinstructional character, both the final goal and the objective between. Second, self-contained is that all of the lesson material from one unit of competency or sub competency learned is in a whole material. Third, stand-alone is a teaching material developed not depending on other teaching materials or should not be used in conjunction with other teaching materials. Fourth, adaptive teaching materials should have high adaptive power in the development of science and technology. Fifth, user friendly is every instruction and display of information that appears helpful and friendly with the wearer, including the ease of users responding and accessing by the wishes.

Then, research is conducted by Kurniawan et al. [15] entitled "The Need Analysis for Teaching Materials as a Reference for Developing the Ball and Tube Wave Physics Models." The research results showed that module teaching materials on the Wave and Tubes course at the University of Jambi are needed to explain the learning material in detail, supplemented with simulations using the MATLAB application.

Accounting education students expected that financial accounting should be aligned with the curriculum, easy to be understood, and fit to the world of work. Students assumed that if the teaching materials are up-to-dated, they could adapt easily to the work environment. The study results show that students likely wanted the values of conservation characters inserted in the lecture. When students studied financial accounting, they wanted values, e.g., creative, honest, caring, tolerant, humane, innovative, and inspirational values in the lecture. The Universitas Negeri Semarang is a conservation university. The character values of Yang developed by Universitas Negeri Semarang are a breath of conservation. The value of conservation character expressed by Handoyo and Tijan [12] is religious, honest, caring, tolerant, or Tepa Slira, democratic, polite, intelligent, and robust. Based on research data, students likely expect teaching materials to visualize the concepts of financial accounting 
courses. The researchers would compile more contextual and interesting teaching materials and complement them with character values to fulfill these needs.

According to Santyasa [16], the benefits of learning with the application of teaching materials are 1) increasing the motivation of students; 2) educators and students know the extent of understanding of the material; 3) students get results according to their abilities; 4) teaching materials are divided more evenly; 5) more efficient because the teaching materials are arranged according to academic levels.

Development of the teaching materials to be carried out refers to the Borg development Procedure and Gall. The scheme of research flows used adapted from the Borg Development Research and Gall [17], namely 1) Research and Information, 2) Planning, 3) Develop a preliminary form of product, 4) preliminary field testing, 5) Operational field testing, 6) Operational product revision, 7) Main field testing, 8) primary product revision, 9) Final product revision, 10) Dissemination and implementation. The model selection is based because allowing the teaching materials maker to continuously revise the evaluation at every stage that can produce better teaching materials. The Borg development Model and Gall is also systematic, yet straightforward in implementing it.

\section{Conclusion}

Based on research data on the need analysis, it can be concluded that teaching materials need to be developed in the Financial Accounting course at the Faculty of Economics, Universitas Negeri Semarang. According to the curriculum, the textbook is contextual learning materials with a clear language to make it easily understood. It complements the values of character conservation to be implemented in the real world.

\section{References}

[1] D. Stephens, "Quality of basic education," Pap. EFA Glob. Monit. Report, http//unesdoc. unesco. org/images/0014/001469/146968e. pdf, 2003.

[2] T. B. B. Education, "Konsep pendidikan kecakapan hidup (life skill education)," Buku I, Kemendikbud, 2001.

[3] A. Mudlofar, "Aplikasi Pengembangan Kurikulum Satuan Tingkat Guruan dan Bahan Ajar dalam Guruan Islam," Jakarta Rajawali Pers, 2012.

[4] I. N. S. Degeng, "Pengaruh Penstrukturan Isi Teks Ajar dan Strategi Belajar Terhadap Perolehan Belajar Menginat Fakta dan Memahami Konsep,” Forum Penelit. Pendidik., vol. 6, no. 1, pp. 74-91, 1989.

[5] Suyatman, Pengembangan Bahan Ajar. Surakarta: Fataba Press IAIN Surakarta, 2013.

[6] D. D. Kristanto, "Pengembangan Modul Fisika RSBI Pokok Bahasan Gerak Pada Siswa Sma Kelas X Semester 1 Sma Negeri 1 Purwareja Klampok." unnes, 2011.

[7] M. Rahmadany and B. N. Achadiyah, "Pengembangan Model Pembelajaran Saintifik Pada Mata Pelajaran Akuntansi Perusahaan Dagang Untuk Siswa Kelas Xi Jurusan Akuntansi,” J. Pendidik. Akunt. Indones., vol. 15, no. 2, pp. 1-11, 2017.

[8] N. A. G. Che Ghani, C. K., Mohd Zaini, O. \& Faeeza, "Competence of instructor in practicing teaching of furniture manufacturing in Malaysia," Sains Humanika, vol. 10, no. 3, pp. 25-32, 2018.

[9] M. Dahlan, D., Permana, L., \& Oktariani, "Teacher Competence and Difficulties In Constructing Hots Instruments In Economics Subject,” J. Cakrawala Pendidik., vol. 39, no. 1, 2020.

[10] N. H. M. Nawi, "Pengajaran dan pembelajaran: penelitian semula konsep-konsep asas menurut 
perspektif gagasan islamisasi ilmu moden," 2011.

[11] M. Hanifah, H. Mohmadisa, S. Yazid, N. Nasir, and N. S. Balkhis, "Competencies For Form Six Geography Teachers In Reaching The Malaysian Education Quality Standards" $J$. Cakrawala Pendidik., vol. 38, no. 2, pp. 243-258, 2019.

[12] \& T. Handoyo, E., Model Pendidikan Karakter Berbasis Konservasi: Pengalaman Universitas Negeri Semarang. Semarang: Cipta Prima Nusantara Semarang, 2010.

[13] H. Irawati and M. F. Saifuddin, "Analisis Kebutuhan Pengembangan Bahan Ajar Mata Kuliah Pengantar Profesi Guru Biologi Di Pendidikan Biologi Universitas Ahmad Dahlan Yogyakarta," BIO-PEDAGOGI, vol. 7, no. 2, pp. 96-99, 2018.

[14] I. Lestari, "Pengembangan bahan ajar berbasis kompetensi," Padang Akad. Permata, vol. 1, 2013.

[15] W. Kurniawan, F. B. Pujaningsih, A. Alrizal, and N. A. Latifah, "Analisis Kebutuhan Mahasiswa terhadap Bahan Ajar sebagai Acuan untuk Pengembangan Modul Fisika Gelombang Bola dan Tabung," Edufisika J. Pendidik. Fis., vol. 3, no. 1, pp. 17-25, 2018.

[16] I. W. Santyasa, "Metode penelitian pengembangan dan teori pengembangan modul," Makal. disampaikan dalam Pelatih. bagi guru-guru dan Dosen di Nusa Penida Klungkung, 2009.

[17] Sugiyono, Metode Penelitian dan Pengembangan (Research and Development/R\&D). Bandung: Alfabeta, 2015. 